\title{
REVIEW
}

\section{Role of oral vaccines as an edible tool to prevent infectious diseases}

\author{
S. SHAKOOR ${ }^{1}$, A. Q. RAO ${ }^{1}$, N. SHAHID ${ }^{1}$, A. YAQOOB ${ }^{1 *}$, T. R. SAMIULLAH ${ }^{1}$, S. SHAKOOR ${ }^{2}$,

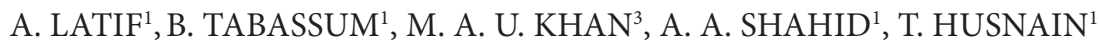 \\ ${ }^{1}$ Centre of Excellence in Molecular Biology, University of the Punjab, 87-West Canal Bank Road Lahore-53700, Pakistan; \\ ${ }^{2}$ Department of Nutrition and Dietetics, Faculty of Medicine and Health Science, University Putra Malaysia; \\ ${ }^{3}$ Faculty of Life Science, University of Central Punjab, Lahore, Pakistan
}

Received September 5, 2018; accepted January 30, 2019

\begin{abstract}
Summary. - Plants have been as medicinal mediators for centuries. Recent trends in agro-biotechnology however, improved the therapeutic roles of plants to a significant level and introduced plant-based oral vaccine which can arouse an immune response in consumer. Although conventional vaccines against infectious diseases have been administrated for years the discovery of plant-based oral vaccines can potentially replace them completely in the future. The probable limitations in conventional vaccines are found to be overcome by plant-based oral vaccines. Humans and animals will no longer be dependent upon local or systemic administration of vaccines but they will just receive the vaccines as a routine food. For the purpose, gene of interest is introduced into plant through transformation, and expression of specific antigen is obtained in plant products which are then consumed by humans or animals. Therefore, plants can serve as bioreactors or bio-factories for production of edible vaccines. A detailed overview about edible vaccines, methods for edible vaccine production, candidate bioreactors and future perspectives of edible vaccines has been summarized in current article. The future of vaccination seems to be present within plant-based vaccination system.
\end{abstract}

Keywords: vaccine; edible vaccine; infectious diseases; antigen; edible crops; oral immunization

\section{Contents:}

1. Threat of infectious diseases and vaccine development

2. Role of plant biotechnology in edible vaccine development

3. Plant-based expression systems

3.1 Nuclear transformation

3.2 Chloroplast transformation

3.3 Viral vectors

3.4 Cell suspension cultures

*Corresponding author. E-mail: aminayaqoob13@gmail.com; phone: +92322-4890733.

Abbreviations: $\mathrm{CTB}=$ cholera toxin $\mathrm{B}$ subunit; FDA = US food and drug administration; GALT = gut associated lymphoid tissue; LTB $=$ heat labile enterotoxin B subunit; USDA = US department of agriculture;VTEC = verocytotoxic Escherichia coli
4. Mechanism of mucosal immune response to edible vaccines

5. Candidate plants for edible vaccines

6. Clinical trials

7. First approved plant-based vaccines

8. Potential problems and challenges of edible vaccines

9. Future perspectives

10. Conclusion

\section{Threat of infectious diseases and vaccine development}

Risk of infectious diseases is not new to the world as it has become a danger for the health of both humans and animals, especially for developing countries. According to World Health Organization, the mortality and morbidity 
rates in developing countries are very high. Almost, 9.5 million people die per year due to the infectious diseases (Lössl and Waheed, 2011).

Infectious diseases in humans are spread mostly by different pathogens. The zoonotic diseases cause almost $65 \%$ of infectious diseases in humans. World is facing a great burden on livestock as well as health of humans and animals due to the infectious and zoonotic diseases about 14,000 years ago when people kept the dogs, goat, sheep, cattle and pigs as domestic animals, zoonotic diseases appeared in humans due their close interaction (Shahid and Daniell, 2016).

The plaque outbreak had spread through rats in Europe that killed a huge proportion of European population. In humans, plaque is the second most deadly disease after smallpox and it has caused millions of deaths as it was the cause 200 million deaths in Black Death pandemic in Europe during $14^{\text {th }}-17^{\text {th }}$ centuries (Alvarez and Cardineau, 2010; Tunkel et al., 2017). It is estimated that 9.4 million cases of illness were caused by 31 animal food borne pathogens each year in United States. In United States, Salmonella is also the main human health risk as it causes almost 400 deaths annually (Routh et al., 2015).

To reduce the rate of infectious diseases in humans and animals, much more efforts and unique prevention strategies are needed. The present review is a brief illustration of various vaccine production systems, vaccine drawbacks, and new plant-produced vaccines to overcome them.

The development of vaccines is based on the scientific idea that prevention is better and economical than treatment. Primarily, vaccination is the exposure of individual to specific antigens of infectious microbe which provokes an immune response in host (Esmael and Hirpa, 2015). Edward Jenner used the vaccination system against "small pox" for the first time in history which opened a new door to discovery of more vaccines against other infectious diseases. Since 1940, several efforts have been carried out to develop vaccines. A great number of vaccines were developed like inactivated vaccines, live vaccines, subunit vaccines and vector vaccines. Most of them had been commercialized later on (Shahid and Daniell, 2016).

Vaccines are proved revolutionary against many infectious diseases but there are some disadvantages i.e. cost effectiveness, adverse side reactions during administration, specific expiration and constant preservation at low temperature (Thomas et al., 2011; Concha et al., 2017). The attenuated vaccines have a good antiviral approach, but at the same time there is a risk of retaining virulence ( $\mathrm{Li}$ et al., 2012). Inactivated vaccines produce less immunity and need multiple boosters (Chen et al., 2008; Perelberg et al., 2005). Moreover, the way of delivering the live vaccine by sprays or aerosol also contaminates the environment. Live virus vaccines can be administered orally or by the nasal route to control many diseases in animals, such as drinking water or through aerosols. Sometimes the aerosol method of administration can accidentally inoculate younger or more susceptible individual in close proximity, leading to death (Wang et al., 2018). The inactive vaccines are administered through intramuscular or subcutaneous injections which are a quite laborious methods to produce very low systemic immunity (Sharma, 1999).

\section{Role of plant biotechnology in edible vaccine development}

In 1990s, Arntzen developed the concept of edible vaccine. A scientific quote, "let the food be the medicine" describes the term edible vaccine very accurately (Lam et al., 1996). Edible vaccines are actually produced in plants by transformation with gene of interest (Lal et al., 2007). The protein derived from the disease-causing pathogen is present in the edible food crop and after the consumption by human or animal the protein enters the bloodstream after digestion. Hence after encounter with pathogen the immune response will neutralize the pathogen (Daniell et al., 2009).

Various plant tissues have been used for the expression of more than 100 types of therapeutic proteins and different types of plant expression systems have been studied (Tiwari et al., 2009). The successful expression of surface antigen present on the surface of Streptococcus mutans in tobacco was the earlier demonstration of edible vaccine (Esmael and Hirpa, 2015). Edible vaccines possess various advantages over conventional vaccines i.e. reduction of possible hazards (toxic compounds), responses to allergies and the risk of establishment of pathogenic strain from attenuated strain, production technologies (that use bacteria, yeast and mammalian cells) (Pelosi et al., 2012). Animals or humans can be immunized equally by the edible vaccines without any risk.

Another limitation of conventional vaccines is its hindrance by physical barriers of host e.g. mucosal surfaces of gut. Comparatively, oral vaccine antigen is protected by the plant cell wall when entering the acidic environment of digestive tract. Conjugation with cholera toxin B subunit (CTB) or heat labile enterotoxin B subunit (LTB) helps to deliver the antigens directly to the gut associated lymphoid tissue (GALT) underneath the epithelia to induce specific immune response (Shahid and Daniell, 2016; Kolotilin et al., 2014).

The first patented edible vaccine was against transmissible gastroenteritis virus (TGEV) in pigs after the demonstration of its efficacy in animal model. However its commercialization is still under process (Lamphear et al., 2004). Edible vaccine against foot and mouth disease and porcine reproductive and respiratory syndrome are currently in clinical trials. Multiple plant-produced edible vaccines against diseases of pets, poultry, and swine, are currently undergoing clinical trials (Esmael and Hirpa, 2015; Jacob et al., 2013). The first 


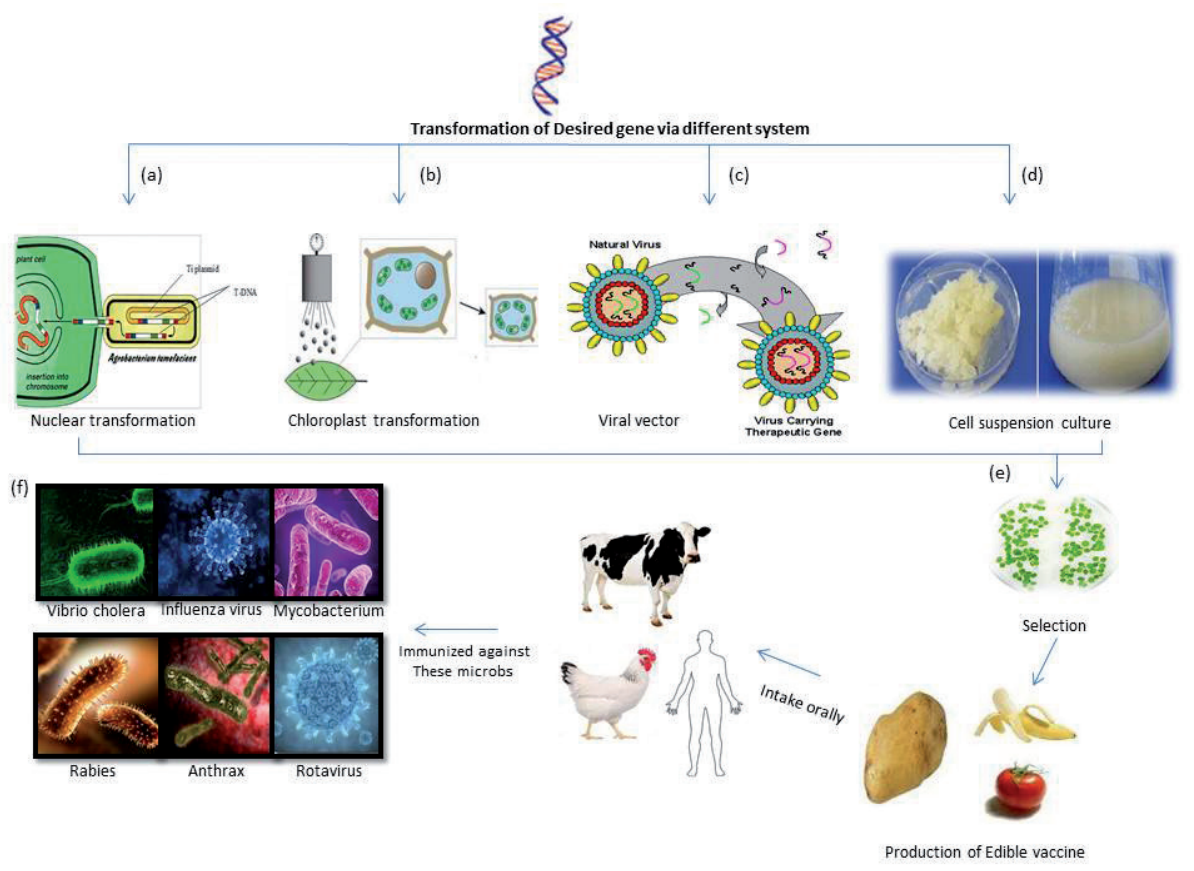

Fig. 1

The production process of plant-made vaccine against infectious diseases

Isolated immunogenic gene from pathogen is introduced into plants through different transformation methods i.e. nuclear transformation, chloroplast transformation, cell suspension based and transient expression. Humans and animals are immunized upon ingestion of plant-made vaccine resulting in specific immune response against infectious diseases.

successful US department of agriculture (in 2006) approved edible vaccine was poultry vaccine against Newcastle disease developed by Dow Agro Sciences. It was the first international success of molecular bio-pharming (Ritala et al., 2014).

\section{Plant-based expression systems}

Production of edible vaccine mainly involves the introduction of gene of interest into host plants via its prior integration into selected vector. Then finally it is integrated into the host's genome where it is expressed either via stable transformation system or through transient transformation system. Selection of system is based on the final location of transgene. Nuclear and plastid integration results in stable transformation system (Laere et al., 2016). Due to the changes in host plant cell after integration into its genome, it is called permanent or stable transformation (Wang et al., 2013a). Genetically modified agrobacterium strain or biolistic transfection are the best examples of stable transfection (Wang et al., 2013a).

On the contrary, when the desired proteins are produced only temporarily after the transformation it is called transient transformation system and gene of interest is not incorporated into the host's genome (Chen and Lai, 2015). It not only produces the significant amount of subunit antigen as compared to the stable transformation system but also the regeneration of whole plant is not required (Fig. 1). It can be achieved through agrobacterium mediated transformation of genetically modified plant virus or particle bombardment (Altpeter et al., 2005). Transformation mechanisms of the genes of interest are discussed below.

\subsection{Nuclear transformation}

Genetically modified crops are mostly produced by nuclear transformation method which is simple and widely used. In this method Agrobacterium tumefaciens or biolistic transformation are used to introduce the foreign antigen into the nuclear genome.

Agrobacterium tumefacien is naturally found in soil and known as soil bacterium. It has the ability to enter into the plants through plant's wounds or scratches. Agrobacterium containing circular tumor inducing Ti plasmid infects the plant after sensing the phenolic secretins from plant's wound (Kim and Yang 2010). Secretins activate the vir genes that are transcribed into vir proteins and mediate the entry and integration of the virus into the host plant's genome that results in the production of hollow tumor called crown gall tumor, where it resides (Sharma and Sood, 2011; Mishra et al., 2008). Transformed cells and the whole plants are selected by antibiotic resistance gene present in the plasmid. 
Agroinfilteration uses vacuum or syringe to transform leaves with agrobacterium containing transgenic gene (Takeyama et al., 2015).

The major advantage of nuclear transformation is the post translational modifications of foreign proteins processed in eukaryotic system. Protein of interest needs a signal peptide to enter nucleus (Tremblay et al., 2010). Along with advantages there are some disadvantages. Foreign DNA integrates randomly into the plant genome thus shows different levels of expression in different parts of the same plant. Almost 50-100 plants has to be transformed at the same time to select the plant with the highest level of expression and lowest number of opposing effect (Santi, 2009). Other disadvantages include gene silencing, position effect and risk of transgene contamination by pollen and seeds (Fahad et al., 2015).

\subsection{Chloroplast transformation}

Chloroplast transformation compensates some of the difficulties of the nuclear transformation that hindered the commercialization as plant based recombinant vaccine. In this method, there is a direct introduction of desired gene (DNA or RNA) into the genome of the circular plant chloroplast through a particle gun. Biolistic method is the most common direct gene delivery approach. It is also called gene gun or micro-projectile method as it does not require any vector for the transfer of gene to the host (Laere et al., 2016). In this method leaves are bombarded with tungsten or gold micro-carrier coated with DNA (Saxena and Rawat, 2014; Kim and Yang, 2010). Micro-carrier coated with the transgene is placed into the gene gun and propelled by high pressure of helium gas toward the leaf (Mishra et al., 2008) and enters the chloroplast and its genome (Vasil and Vasil, 1999).

Most of the recently reported edible vaccines are produced via chloroplast transformation due to the stability and high expression of the gene. Risk of transgene via pollen is reduced because of the maternally inherited chloroplast genome. Many antigens of viral and bacterial origin against various animal and plant diseases including cholera, anthrax, tetanus, plaque and against viral diseases including rotavirus and canine parvovirus were expressed in chloroplasts (RosalesMendoza et al., 2012).

\subsection{Viral vectors}

Natural hosts such as edible plants can be infected through the genetically engineered plant viruses that carry the gene of interest. Different levels of expression of cloned genes are seen in different parts of the plants including edible portions (Saxena and Rawat, 2014). Certain viruses including cowpea mosaic viruses (CPMV), alfalfa mosaic virus, tobacco mosaic virus (TMV), cauliflower mosaic virus (CaMV), tomato bushy stunt virus and potato virus are engineered to express the portion of antigenic protein on their surface through overcoat and epicoat technology. The entire proteins of the virus are produced by overcoat technology. While the expression of only the foreign protein can be produced by epicoat technology (Esmael and Hirpa, 2015).

The plant virus is genetically modified, to express the foreign gene under the control of coat protein sub-genomic promoter. These modified viruses are used to deliver epitope peptide into the plant. The whole process takes 3 weeks (Gleba et al., 2007). Vaccine against rabies virus in alfalfa was produced by using virus vector system. Plant viruses produce the abundant protein in short time after its independent transcription and translation (Rybicki, 2014).

\subsection{Cell suspension cultures}

Plants are cultivated by several in vitro techniques but cultivation through cell suspension culture has a great interest for the scientists because it is the most responsive procedure for the production of genetically modified transgenic plants that can easily be cultivated in large scale bioreactors. Cell suspension cultures are prepared by the distortion of single callus into undifferentiated cells that result in the stable cell suspension (Yusibov and Rabindran, 2008). Transgenic explants are transformed with the agrobacterium to produce the recombinant protein. Tobacco cell suspension has been used for the production of first edible vaccine against poultry disease that was approved by the USDA in 2006 (Yusibov et al., 2011). FDA approved the first biopharmaceutical protein glucocerebrisidase against Gaucher's disease made in carrot cells in 2012 which is now marketed by Pfizer (Wolfson, 2013).

\section{Mechanism of mucosal immune response to edible vaccines}

Digestive, respiratory and reproductive tracts are lined with largest immunological active tissue in the body called mucosal surface. It is also called gut associate lymphoid tissue (GALT) that in humans has an area of $300 \mathrm{~m}^{2}$. Both mucosal and humoral immunity response can be stimulated by the plant-produced vaccines. The antigen in transgenic edible plant is protected from the gastric secretions by the tough outer wall of plant cell that acts as bio-encapsulation during its delivery and finally breaks up in the intestine (Wang et al., 2013b). M cells present over the Peyer's patches and GALT ingest the released antigen and then pass it on to macrophages, local lymphocytes and other antigen presenting cells. Consequently, the level of IgG, IgA and $\operatorname{IgE}$ antibodies in the serum increases. Finally, the target molecules on subsequent exposure are neutralized by these antibodies. In this way, GALT plays crucial role in the oral immunization by edible vaccine (Pasetti et al., 2011; Shahid et al., 2017). 
Table 1. Summary of the vaccines antigens against different diseases of humans and animals expressed in different expression systems

\begin{tabular}{|c|c|c|c|c|}
\hline Diseases & Antigen & Expression host & Immune response & References \\
\hline \multicolumn{5}{|c|}{ Infectious diseases of humans } \\
\hline Hepatitis B & HBsAg & banana, potato/nuclear & $\begin{array}{l}\text { maximum level of HBsAg expression seen in } \\
\text { leaves, generate systematic response in hu- } \\
\text { man gut }\end{array}$ & Rukavtsova et al., 2015 \\
\hline Botulism & $\mathrm{BoHc}$ & rice/nuclear & induction of specific IgA and IgC antibodies & Yuki et al., 2012 \\
\hline Rotaviral diarrhea & eBRV4 & alfalfa/transplastomic & induction of lactogenic immunity & Wigdorovitz et al., 2004 \\
\hline Tuberculosis & CFP10, ESAT6 & carrot/nuclear & $\begin{array}{l}\text { induction of cell-mediated and humoral re- } \\
\text { sponse }\end{array}$ & Uvarova et al., 2013 \\
\hline Gastroenteritis & LTB;ST & tobacco/transplastomic & $\begin{array}{l}\text { induction of specific mucosal and systematic } \\
\text { antibodies }\end{array}$ & $\begin{array}{l}\text { Rosales-Mendoza et al., } \\
2011\end{array}$ \\
\hline AIDS & $\mathrm{P} 24, \mathrm{Nef}$ & tobacco/transplastomic & stimulation of IgG antibodies & $\begin{array}{l}\text { Gonzalez-Rabade et al., } \\
2011\end{array}$ \\
\hline Cervical cancer & HPV16L1 & tobacco/nuclear & $\begin{array}{l}\text { specific IgG and IgA antibodies are produced, } \\
\text { induction of cell-mediated immune response }\end{array}$ & Hongli et al., 2013 \\
\hline Cholera & CTB & rice/nuclear & induction of CTB specific IgG and IgA & Yuki et al., 2012 \\
\hline \multicolumn{5}{|c|}{ Infectious diseases of animals } \\
\hline Anthrax & $\mathrm{PA}$ & tobacco/transplastomic & $\begin{array}{l}\text { protection against anthrax by the induction of } \\
\text { specific IgG and IgA antibodies }\end{array}$ & Gorantala et al., 2014 \\
\hline Swine edema disease & Vt2e-B-\&FedA & tobacco/nuclear & $\begin{array}{l}\text { induction of specific IgG and IgA antibodies } \\
\text { and protection against verocytotoxic E. coli } \\
\text { infection }\end{array}$ & Legocki et al., 2005 \\
\hline $\begin{array}{l}\text { Porcine reproductive and } \\
\text { respiratory syndrome }\end{array}$ & $\begin{array}{l}\text { PRRS virus matrix } \\
\text { protein }\end{array}$ & maize/nuclear & $\begin{array}{l}\text { detection of cellular immune response by } \\
\text { PRRSV specific IFN gamma }\end{array}$ & Chia et al., 2010 \\
\hline Rabies virus & $\begin{array}{l}\text { G Protein of rabies } \\
\text { virus }\end{array}$ & carrot/nuclear & $\begin{array}{l}\text { induction of specific igG and IgA antibodies } \\
\text { and protection against rabies virus }\end{array}$ & Rojas-Anaya et al., 2009 \\
\hline \multirow[t]{2}{*}{$\begin{array}{l}\text { Bird flu avian influenza } \\
\text { virus }\end{array}$} & $\mathrm{NP}$ of $\mathrm{H} 3 \mathrm{~N} 2$ & maize/nuclear & $\begin{array}{l}\text { induction of specific } \operatorname{IgA}, \operatorname{IgG}, \operatorname{IgG} 2, \mathrm{TH} 1, \mathrm{TH} 2 \\
\text { in immunized mice }\end{array}$ & Lee et al., 2015 \\
\hline & NA gene of $\mathrm{H} 1 \mathrm{~N} 1$ & lettuce/nuclear & $\begin{array}{l}\text { significant anti-NA antibodies were produced } \\
\text { in orally immunized mice }\end{array}$ & Liu et al., 2012 \\
\hline Toxoplasmosis & Gra4 & tobacco/transplastomic & $\begin{array}{l}\text { cellular and mucosal immune response were } \\
\text { produced }\end{array}$ & Yácono et al., 2012 \\
\hline
\end{tabular}

\section{Candidate plants for edible vaccines}

For the expression of desired antigen different edible parts (like grains or fruits) of different plant species are utilized. For the high level of expression cereals (e.g. rice and maize), fruits (e.g. banana), leaves of many plants (e.g. tobacco, alfalfa and peanut), tubers (e.g. potato), tomatoes, pea, cowpea, soybean seeds, carrot and lettuce have been largely used (Ahmad et al., 2012; Yoshimatsu et al., 2012; Huy et al., 2012). An attention should payed to choosing the characteristics of the plant for antigen expression i.e. hardy, palatable, well relished, native, easily accessible and easy to transform. Another major aspect is site of expression, whether the antigen is expressed in leaves of germinating seedlings or in chloroplast or in dry tissue like cereals as a final vaccine product (Wang et al., 2012).

Expression in grains has an advantage over others as it is cost effective, large proteins can be stored in it for years, massive production in short time span and finally it can be harvested and processed very easily (Streatfield et al., 2001).
Because of transforming ability tobacco is the plant that is commonly utilized for the expression of proteins. The aim of using transgenic plants is the production of vaccines that can facilitate easier delivery of vaccine antigen resulting in the boost up of immune system against various infectious diseases in short period of time (Santi, 2009; Rybicki, 2010). Examples of plants recently used for edible vaccines include banana, rice, alfalfa, potato, tomato and maize and are discussed briefly below (Table 1). All these edible vaccines have promising results in animal models.

Verocytotoxic Escherichia coli (VTEC) strains cause swine edema diseases in pigs which results in big economic losses in the pig's industry. Seed-based (Nicotiana tabacum) edible vaccine against VTEC tested in clinical trials in 36 piglets, resulted in the increased level of IgAs against VTEC as compared to control (Lombardi, 2017).

There is no licensed vaccine available for the treatment of hepatitis $\mathrm{C}$ virus (HCV) till this date. Recently, edible vaccine against $\mathrm{HCV}$ was produced in edible crop (lettuce, Lactuca sativa) by targeting E1E2 dimer. Activity of this vaccine was 
analyzed in immunized mice that resulted in the development of weak serum level of anti-HCV IgM against targeted antigen (Clarke et al., 2017).

Other therapeutics that have been produced in various transgenic plants such as insulin in transgenic sunflower (Sem BioSys), growth factor in transgenic barley (ORF Genetics), taliglucerase alfa in transgenic carrot (ProtalixBioTherapeutics), avian influenza vaccine in transgenic tobacco (Medicago), and Ebola vaccine in transgenic tobacco (Mapp Biopharmaceutical) were proved very effective and had shown very promising results in animal model (mouse) (Laere et al., 2016).

\section{Clinical trials}

Although many plant-produced vaccines are still in phase I clinical trials, some have completed phases II and III trials e.g. edible vaccine against LTB is in phase I clinical trial. Edible vaccine against $B$ subunit of the heat labile enterotoxin (LTB) of the enterotoxigenic E. coli expressed in either potato or maize was orally administered to the healthy volunteers. After 50 days serological test showed the increased level of anti-LTB IgG and IgA in serum (Yusibov et al., 2015). Other edible vaccines in phase I clinical trials include norvovirus capsid protein in potato and CTB in rice. Plant-produced vaccines against influenza virus strains $\mathrm{H} 1 \mathrm{~N} 1, \mathrm{H} 7 \mathrm{~N} 9, \mathrm{H} 5 \mathrm{NI}$ produced in Nicotiana benthamiana are in phase I clinical trial except vaccine against $\mathrm{H} 5 \mathrm{~N} 1$ that is in phase II clinical trial, however they all are administered intramuscularly (Takeyama et al., 2015).

\section{First approved plant-based vaccines}

Dow Agro Sciences officially received approval for producing the first plant-based vaccine against Newcastle disease virus (NDV) from the United States Department of Agriculture (USDA). Dow Agro Sciences developed a plant-based vaccine (injectable) against NDV in tobacco cell suspension. The USDA accepted plant-based vaccine against NDV in 2006 after observing 90\% protection against a high quantity of viral antigen. This system has ability to produce abundance of vaccine antigen in short period, but the company did not approach the production, because it was developed in tobacco cell suspension, although, it needs an injectable delivery mode (Yusibov et al., 2011). Another US patent (20050048074) has been issued to vaccine for plant cells transformed with the HN gene protecting chickens from NDV (Yusibov et al., 2011). FDA approved another plantbased therapeutics in 2012 expressing glucocerbrocidase in carrot cell suspension, which is also a great achievement in the field of plant-based vaccines (Ruiz et al., 2015).

\section{Potential problems and challenges with edible vaccines}

Although the edible vaccine production against different infectious diseases of humans and animals are still at an early stage, after considering its positive outcomes, it is thought that its development will become reality in near future. The goal behind the production of edible vaccine was to get the immunization by feeding edible portion of plant directly, however the concentration of antigen in different parts of plant is not the same and makes it difficult to standardize the vaccine dose (Lindh et al., 2012, 2014).

The final product formulation, safety, efficacy and longterm stability in field conditions are also concern. Ethical concerns are also raised by the use of edible vaccine, most importantly whether the edible vaccines are considered foodstuff or medicine. It is becoming an alarming situation among population because edible vaccine itself is a genetically modified organism, it is becoming concern for people's religious beliefs. However the in and out of any biological tool depends upon the people who are developing them and the way they are regulated (Concha et al., 2017).

Bioterrorism is also becoming a serious challenge to the global safety and public health due to the mis-management of the transgenic edible crops by ill-intentioned purpose. As a result, both developed and developing countries must take a step to define the regulations that would be followed globally to avoid bioterrorism (Zapanta and Ghorab, 2014).

FDA makes sure the safety of both synthetic and plantbased vaccine in the United States and also licenses them after approval. The United State Department of Agriculture (USDA) also contributes a lot in this regard by approving veterinary vaccines and considering the nature of the plant, chances of cross contamination, genetic background of the transgenic plant and risk management strategies. The European Medicine Agency (EMA) complement the FDA and USDA regulations (Takeyama et al., 2015).

\section{Future perspectives}

There is a need to develop and scale the simple procedures for downstream processing and formulation for plant-based vaccines. Edible vaccines are likely to be used in third world countries where it saves transportation costs, avoids refrigeration and administrations orally without needle use. Increase in the immunogenicity of oral antigens is another advancement to be attained. Avoiding the stimulation of peripheral immune tolerance to the antigen that is taken orally, sublingually or by nasal route that suppresses the humoral immune response, is an area where further research is still needed. 
Coffee plant and natural grass which are commonly consumed by humans and animals should be considered for the production of edible vaccines in near future. Awareness about the use of edible vaccine in developing countries should be developed. These issues must be considered to make the edible vaccine that can meet the excellence standards set by World Health Organization.

\section{Conclusion}

In last decade,great research has been done and still continues to develop the edible vaccine against the infectious diseases of humans and animals. Hence, vaccination via edible plants may be considered as to secure the future in terms of safe and effective immunization. Edible vaccines would overcome the problems associated with traditional vaccines like use of needle, less production, complications to attain immunization, high cost and transportation. Although there is a variation in the expression level of antigen in different edible plants and their parts but this can be overcome by the further research to disclose the secret of uniform expression in all parts of plants. It can become reality only when transgenic plant-based vaccine will be able to overcome all the challenges.

\section{References}

Ahmad P, Ashraf M, Younis M, Hu X, Kumar A, Akram NA, AlQurainy F, Biotechnol. Adv. 30, 524-540, 2012. https:// doi.org/10.1016/j.biotechadv.2011.09.006

Altpeter F, Baisakh N, Beachy R, Bock R, Capell T, Christou P, Daniell H, Datta K, Datta S, Dix PJ, Fauquet C, Mol. Breed. 15, 305-327, 2005. https://doi.org/10.1007/s11032-004-8001-y

Alvarez LM, Cardineau GA, Biotechnol. Adv. 28, 184-196, 2010. https://doi.org/10.1016/j.biotechadv.2009.11.006

Chen Q, Lai H. Biomed Res. Int. 2015, 1-10, 2015. https://doi. org/10.1155/2015/932161

Chen MW, Cheng TJR, Huang Y, Jan JT, Ma SH, Alice LY, Wong CH, Ho DD, Proc. Natl. Acad. Sci. 105, 13538-13543, 2008. https://doi.org/10.1073/pnas.0806901105

Chia MY, Hsiao SH, Chan HT, Do YY, Huang PL, Chang HW, Tsai YC, Lin CM, Pang VF, Jeng CR, Vet. Immunol. Immunopathol. 135, 234-242, 2010. https://doi.org/10.1016/j. vetimm.2009.12.003

Clarke JL, Paruch L, Dobrica MO, Caras I, Tucureanu C, Onu A, Ciulean S, Stavaru C, Eerde A, Wang Y, Steen H, Haugslien S, Petrareanu C, Lazar C, Popescu CI, Bock R, Dubuisson J, Branza-Nichita N, Plant. Biotechnol. J. 15, 1611-1621, 2017. https://doi.org/10.1111/pbi. 12743

Concha C, Cañas R, Macuer J, Torres MJ, Herrada AA, Jamett F, Ibáñez C, Vaccines 5, 1-23, 2017. https://doi.org/10.3390/ vaccines 5020014

Daniell H, Singh ND, Mason H, Streatfield SJ, Trends. Plant. Sci. 14, 669-79, 2009. https://doi.org/10.1016/j. tplants.2009.09.009
Esmael H, Hirpa EJ, Nutr. 4, 40-49, 2015. https://doi.org/10.1080 103632415.2015.1006501

Fahad F, Khan FA, Pandupuspitasari NS, Ahmed MM, Liao YC, Waheed MT, Sameeullah M, Hussain S, Saud S, Hassan S, Jan A, Biotechnol. Lett. 37, 265-279, 2015. https://doi. org/10.1007/s10529-014-1699-7

Gleba Y, Klimyuk V, Marillonnet S, Curr. Opin. Biotechnol.18, 134141, 2007. https://doi.org/10.1016/j.copbio.2007.03.002

Gonzalez-Rabade N, McGowan EG, Zhou F, McCabe MS, Bock R, Dix PJ, Gray JC, Ma JK-C, Plant. Biotechnol. J. 9, 629-638, 2011. https://doi.org/10.1111/j.1467-7652.2011.00609.x

Gorantala J, Grover S, Rahi A, Chaudhary P, Rajwanshi R, Sarin NB, Bhatnagar RJ, Biotechnol. 176, 1-10, 2014. https:// doi.org/10.1016/j.jbiotec.2014.01.033

Hongli L, Xukui L, Ting L, Wensheng L, Lusheng S, Jin Z, Hum. Vaccines Immunother. 9, 83-89, 2013. https://doi. org/10.4161/hv.22292

Huy N-X, Kim S-H, Yang M-S, Kim T-G, Plant. Cell Rep. 31,19331942, 2012 https://doi.org/10.1007/s00299-012-1306-0

Jacob SS, Cherian S, Sumithra TG, Raina OK, Sankar M, Vaccine 31, 1879-1885, 2013. https://doi.org/10.1016/j.vaccine.2013.02.022

Kim TG, Yang M-S, Biotechnol. Bioprocess. Eng. 15, 61-65, 2010. https://doi.org/10.1007/s12257-009-3084-2

Kolotilin I, Topp E, Cox E, Devriendt B, Conrad U, Joensuu J, Stöger E, Warzecha H, McAllister T, Potter A, McLean MD, Hall JC, Manassa R, Vet. Res. 45, 117, 2014. https:// doi.org/10.1186/s13567-014-0117-4

Laere E, Ling APK, Wong YP, Koh RY, Lila MAM, Hussein SJ. Botany 2016, 1-11, 2016. https://doi.org/10.1155/2016/4928637

Lal P, Ramachandran VG, Goyal R, Sharma R, Indian J. Med. Microbiol. 25, 93-102, 2007. https://doi.org/10.4103/0255$\underline{0857.32713}$

Lam DM, Arntzen CJ, inventors; Edible Vaccines Inc, assignee. United States patent US 5484719A, 1996

Lamphear BJ, Jilka JM, Kesl L, Welter M, Howard JA, Streatfield SJ, Vaccine 22, 2420-2424, 2004. https://doi.org/10.1016/j. vaccine.2003.11.066

Lee G, Na YJ, Yang BG, Choi JP, Seo YB, Hong CP, Yun CH, Kim DH, Sohn EJ, Kim JH, Sung YC, Kim YK, Jang MH, Hwang I, Plant Biotechnol. J. 13, 62-72, 2015. https:// doi.org/10.1111/pbi.12235

Legocki AB, Miedzinska K, Czaplińska M, Płucieniczak A, Wędrychowicz H, Vaccine 23, 1844-1846, 2005. https:// doi.org/10.1016/j.vaccine.2004.11.015

Li GM, Chiu C, Wrammert J, McCausland M, Andrews SF, Zheng NY, Lee JH, Huang M, Qu X, Edupuganti S, Mulligan M, Das SR, Yewdell JW, Mehta AK, Wilson PC, Ahmed R, Proc. Natl. Acad. Sci. USA 109, 9047-9052, 2012. https:// doi.org/10.1073/pnas.1118979109

Lindh I, Bråve A, Hallengärd D, Hadad R, Kalbina I, Strid A, Andersson S, Vaccine 32, 2288-2293, 2014. https://doi. org/10.1016/j.vaccine.2014.02.073

Lindh I, Bråve A, Hallengärd D, Haddad R, Strid A, Andersson S, Retrovirology 9, 336, 2012. https://doi.org/10.1186/17424690-9-S2-P336

Liu CW, Chen JJW, Kang CC, Wu CH, Yiu JC, Sci. Hortic. 139, 8-13, 2012. https://doi.org/10.1016/j.scienta.2012.02.037 
Lombardi A (2017): Molecular farming applied to veterinary science: nicotiana tabacum plants expressing antigenic proteins from Escherichia coli as a model of edible vaccine in weaned piglets. PhD thesis, https://air.unimi.it/ handle/2434/489689\#.XPGZPPZuJ9A.

Lössl AG, Waheed MT, Plant Biotechnol. J. 9, 527-539, 2011. https:// doi.org/10.1111/j.1467-7652.2011.00615.x

Mishra N, Gupta PN, Khatri K, Goyal AK, Vyas SP, Indian J. Biotechnol. 7, 283-294, 2008.

Pasetti MF, Simon JK, Sztein MB, Levine MM, Immunol. Rev. 239, 125-148, 2011. https://doi.org/10.1111/j.1600065X.2010.00970.x

Pelosi A, Shepherd R, Walmsley AM, Biotechnol. Adv. 30, 440-448, 2012. https://doi.org/10.1016/j.biotechadv.2011.07.018

Perelberg A, Ronen A, Hutoran M, Smith Y, Kotler M, Vaccine 23, 3396-3403, 2005. https://doi.org/10.1016/j.vaccine.2005.01.096

Ritala A, Häkkinen ST, Schillberg S, Pharm. Bioprocess 2, 223-226, 2014. https://doi.org/10.4155/pbp.14.21

Rojas-Anaya E, Loza-Rubio E, Olivera-Flores MT, Gomez-Lim M, Transgenic. Res. 18, 911-919, 2009. https://doi. org/10.1007/s11248-009-9278-8

Rosales-Mendoza S, Govea-Alonso DO, Monreal-Escalante E, Fragoso G, Sciutto E, Vaccine 31, 40-48, 2012. https:// doi.org/10.1016/j.vaccine.2012.10.094

Rosales-Mendoza S, Soria-Guerra RE, Moreno-Fierros L, GoveaAlonso DO, Herrera-Díaz A, Korban SS, Alpuche-Solís ÁG, Plant Cell. Rep. 30, 1145-1152, 2011. https://doi. org/10.1007/s00299-011-1023-0

Routh JA, Pringle J, Mohr M, Bidol S, Arends K, Adams-Cameron M, Hancock WT, Kissler B, Rickert R, Folster J, Tolar B, Bosch S, Barton Behravesh C, Williams IT, Gieraltowski L, Epidemiol. Infect. 143, 3227-3234, 2015. https://doi. org/10.1017/S0950268815000497

Ruiz V, Mozgovoj MV, Santos MJD, Wigdorovitz A. Plant Biotechnol J. 13, 1071-1077, 2015. https://doi.org/10.1111/ pbi. 12440

Rukavtsova EB, Rudenko NV, Puchko EN, Zakharchenko NS, Buryanov YI, J. Biotechnol. 203, 84-88, 2015. https://doi. org/10.1016/j.jbiotec.2015.03.019

Rybicki EP, Plant Biotechnol. J. 8, 620-637, 2010. https://doi. org/10.1111/j.1467-7652.2010.00507.x

Rybicki EP, Virol. J. 11, 205, 2014. https://doi.org/10.1186/PREACCEPT-2088894788140228

Santi L, Vet. Res. Comm. 33, 61-66, 2009. https://doi.org/10.1007/ s11259-009-9246-Z

Saxena J, Rawat S, In Adv. in Biotechnol. 207-226, 2014. Springer, New Delhi. https://doi.org/10.1007/978-81-322-1554-7 12

Shahid N, Daniell H, Plant. Biotechnol. J. 14, 2079-2099, 2016. https://doi.org/10.1111/pbi.12604

Shahid N, Rao AQ, Kristen PE, Ali MA, Tabassum B, Umar S, Tahir S, Latif A, Ahad A, Shahid AA, Husnain T, Worlds Poult. Sci. J. 73, 471-482, 2017. https://doi.org/10.1017/ $\underline{\text { S0043933917000484 }}$

Sharma JM, Adv. Vet. Med. 41, 481-494, 1999. https://doi. org/10.1016/S0065-3519(99)80036-6

Sharma M, Sood B, World J. Microbiol. Biotechnol. 27, 471-477, 2011. https://doi.org/10.1007/s11274-010-0481-9
Streatfield SJ, Jilka JM, Hood EE, Turner DD, Bailey MR, Mayor JM, Woodard SL, Beifuss KK, Horn ME, Delaney DE, Tizard IR, Howard JA, Vaccine 19, 2742-2748, 2001. https://doi. org/10.1016/S0264-410X(00)00512-0

Takeyama N, Kiyono H, Yuki Y, Ther. Adv. Vaccines 3,139-154, 2015. https://doi.org/10.1177/2051013615613272

Thomas DR, Penney CA, Majumder A, Walmsley AM, Int. J. Mol. Sci. 12, 3220-3236, 2011. https://doi.org/10.3390/ ijms12053220

Tiwari S, Verma PC, Singh PK, Tuli R, Biotechnol. Adv. 27, 449-467, 2009. https://doi.org/10.1016/j.biotechadv.2009.03.006

Tremblay R, Wang D, Jevnikar AM, Shengwu Ma, Biotechnol. Adv. 28, 214-221, 2010. https://doi.org/10.1016/j.biotechadv.2009.11.008

Tunkel AR, Hasbun R, Bhimraj A, Byers K, Kaplan SL, Scheld WM, van de Beek D, Bleck TP, Garton HJL, Zunt JR, Clin. Infect. Dis. 64, e34-e65, 2017. https://doi.org/10.1093/ cid/ciw861

Uvarova EA, Belavin PA, Permyakova NV, Zagorskaya AA, Nosareva OV, Kakimzhanova AA, Deineko EV, Biomed. Res. Int. 2013, 1-8, 2013. https://doi.org/10.1155/2013/316304

Vasil IK, Vasil V, In Plant Cell Culture Protocols. Humana Press. 349-358, 1999.

Wang P, Lin L, Li H, Shi M, Gu Z, Wei P, Transbound. Emerg. Dis. 65, 1103-1106, 2018. https://doi.org/10.1111/tbed.12841

Wang W, Li W, Ma N, Steinhoff G, Curr Pharm. Biotechnol. 14, 4660, 2013a. https://doi.org/10.2174/138920113804805278

Wang X, Sherman A, Liao G, Leong KW, Daniell H, Terhorst C, Herzog RW, Adv. Drug Deliv. Rev. 65, 759-773, 2013 b. https://doi.org/10.1016/j.addr.2012.10.013

Wang Y, Shen Q, Jiang Y, Song Y, Fang L, Xiao S, Chen H, J. Virol. Methods. 181, 12-17, 2012. https://doi.org/10.1016/j. jviromet.2012.01.004

Wigdorovitz A, Mozgovoj M, Santos MJ, Parreno V, Gomez C, Perez-Filgueira M, Trono K, Ríos RD, Franzone PM, Fernandez F, Carrillo C, Babiuk L, Escribano JM, Borca MV, J. Gen. Virol. 85, 1825-1832, 2004.

Wolfson W. Chem. Biol. 20, 969-970, 2013. https://doi.org/10.1016/j. chembiol.2013.08.003

Yácono ML, Cono LY, Farran I, Becher ML, Sander V, Sanchez VR, Martín V, Veramendi J, Clemente M, Plant Biotechnol. J. 10, 1136-1144, 2012. https://doi.org/10.1111/pbi.12001

Yoshimatsu K, Kawano N, Kawahara N, Akiyama H, Teshima R, Nishijima M. Yakugaku Zasshi. J, Pharm Soc. Japan 132, 629-674, 2012. https://doi.org/10.1248/yakushi.132.629

Yuki Y, Mejima M, Kurokawa S, Hiroiwa T, Kong IG, Kuroda M, Takahashi Y, Nochi T, Tokuhara D, Kohda T, Vaccine 30, 4160-4166, 2012. https://doi.org/10.1016/j.vaccine.2012.04.064

Yusibov V, Kushnir N, Streatfield SJ, Expert Rev. Vaccines 14, 519 535, 2015. https://doi.org/10.1586/14760584.2015.989988

Yusibov V, Streatfield SJ, Kushnir N, Hum. Vaccines 7, 313-321, 2011. https://doi.org/10.4161/hv.7.3.14207

Yusibov V, Rabindran S, Expert Rev. Vaccines 7, 1173-1183, 2008. https://doi.org/10.1586/14760584.7.8.1173

Zapanta PE, Ghorab S, Otolaryngol. Head Neck Surg. 151, 208-214, 2014. https://doi.org/10.1177/0194599814531907 